\title{
THE VALUE AND THE SACRIFICE PERCEIVED BY VEGETARIAN FOOD CONSUMERS
}

\author{
OS VALORES E OS SACRIFÍCIOS PERCEBIDOS PELOS CONSUMIDORES \\ DE COMIDA VEGETARIANA
}

\author{
Recebido em 03.01.2018. Aprovado em 30.01.2018 \\ Avaliado pelo sistema double blind review \\ DOI: http://dx.doi.org/10.12712/rpca.v12i1.1181
}

\section{Rhaimá Aparecida Mendonça da Costa Birchal \\ Centro Universitário de Belo Horizonte (UniBH), Belo Horizonte/MG, BRASIL \\ rhaimacosta@gmail.com}

\author{
Luiz Rodrigo Cunha Moura \\ Centro Universitário UNA, , Belo Horizonte/MG, BRASIL \\ luizrcmoura@gmail.com
}

\author{
Fernanda Carla Wasner Vasconcelos \\ Centro Universitário UNA, , Belo Horizonte/MG, BRASIL \\ fernanda.wasner@prof.una.br
}

\author{
Nina Rosa da Silveira Cunha \\ Universidade Federal de Viçosa (UFV), Viçosa/MG, BRASIL \\ ninarosa@ufv.br
}

\begin{abstract}
This study aimed to identify what are the items that make up the categories of value and sacrifice perceived by the consumer of vegetarian food. It's an exploratory research and fifteen vegetarians were interviewed through a structured interview script and the data were analyzed by means of content analysis. The results indicate the existence of functional (physical and mental well-being, as well as healthy food), social (perception that being a vegetarian is something positive), emotional (more peaceful feeling, with a clean conscience), conditional (ease of access and variety of vegetarian food) and monetary values for vegetarians. There are also sacrifices, in the same dimensions (functional, social, emotional, conditional and monetary) as nutrients deficiency, incomprehension of other people, perception of "boredom" of vegetarians, among others. This study improves the knowledge of the components of perceived value and perceived sacrifice by the vegetarian consumers, serving as a base for further researches.
\end{abstract}

Keywords: Consumer' Perception. Perceived Value. Perceived Sacrifice. Vegetarian. Vegetarian Food.

\section{Resumo}

Este estudo teve como objetivo identificar quais são os itens que compõem as categorias de valor e sacrifício percebidas pelo consumidor de comida vegetariana. Essa é uma pesquisa exploratória e quinze vegetarianos foram entrevistados através de um roteiro de entrevista estruturado e os dados foram analisados por meio de análise de conteúdo. Os resultados indicam que há valores funcionais (bem estar físico e mental, como também um alimento saudável), sociais (percepção de que ser vegetariano é uma coisa positiva), emocionais (sentimento de maior tranquilidade, com uma consciência limpa), condicionais (facilidade de acesso e variedade de comida vegetariana) e monetários para os vegetarianos. Existem, também, sacrifícios, nas mesmas dimensões (funcionais, sociais, emocionais, condicionais e monetários) tais como deficiência de nutrientes, incompreensão de outras pessoas, percepção de tédio dos vegetarianos, entre outros. Este estudo melhora o conhecimento dos componentes de valor e de sacrifício percebidos pelo consumidor vegetariano servindo como base para outras pesquisas.

Palavras-chave: Pecepção do Consumidor. Valor Percebido. Sacrifício Percebido. Vegetariano. Comida Vegetariana. 


\section{Introduction}

There is in the society a movement toward concern with health and environmental outcomes of the production and consumption of meat, as well as animal well-being. Consequently, a growing number of people have rethought their eating habits, opting for a vegetarian diet, not consuming meat anymore, and even abdicating the animal derivatives consumption (FRANCO; REGO, 2005).

In this sense, among the discussions about eating habits that go beyond the functional aspects of the food, and that shows concern with the aspect of health and sustainability (environmental, social and economic) (MOURA, 2010), the vegetarianism has been gaining attention and space (SOUZA et al., 2013).

Thus, the development of discussions, practices and trends of consumption on the vegetarian diet, are shown in the following marketing actions: at the opening of university courses that address the vegetarian nutrition and animal rights, the increase in the number of vehicles of communication (websites, magazines, and books) addressing the vegetarian cuisine, the growing number of people looking for vegetarian meal outside the domicile (CRAIG; MANGELS, 2009), besides the availability of more information at libraries, bookstores, restaurants, expansion of the number of stores with vegetarian menu, availability of a greater variety of products without meat in traditional food stores and in the increasing of the number of small-sized stores involved with vegetarianism (REZENDE, 2014).

Although the vegetarian market has been growing, adepts of this type of diet still face difficulties in consumption because both Brazil and other countries have not dedicated efforts to provide services to this type of consumer, who considers consumption as a way of construction and expression of identity. There are many motivations (ethical, religious, social, economic, health and environment concerns, among others) for vegetarianism and consequent variety of thoughts and attitudes, so it is recommended that they become subject to academic studies aiming at a better understanding of this group of consumers (RODRIGUES, 2012).

Therefore, the goal of this work was to identify the aspects of perceived value and perceived sacrifices by the consumers on vegetarian food and classify them into categories.
In theoretical terms, this study might contribute to Brazilian literature on the subject. This is because the results obtained in the search for the term "Vegetarian Consumer Behavior", carried out in Google Scholar restricting the period between the years from 2006 to 2016 - found only three studies, two of them similar and written by the same authors. Aiming at extrapolating such results, the same research was performed in the platforms Scielo (Scientific Electronic Library Online) and Cengage; but in both, no registration of works regarding the themes were found.

In relation to the managerial implications of this research, it could be noted that from the information obtained in this research the managers can deliver more value to their customers, enabling the differentiation of their products and services, and thus, being more competitive in comparison with their competitors. Furthermore, the managers will also be able to identify what are the most important aspects for the consumers and, consequently, they may influence their decision-making process by offering more value for these vegetarian food consumers.

In studies on consumer behavior it is fundamental to try to know the reasons that make consumers decide to purchase products, since they assess differently the attributes with respect to their importance. Therefore, aiming at better decision-making, marketing professionals must understand the value perception of consumers and the most important attributes in the purchaser's judgement (MOURA et al., 2015; MOWEN; MINOR, 2003; ESPINOZA; HIRANO, 2003).

Regarding social terms, it is important to consider the growth in the number of supporters of this diet, as shown by the results of the research made in 2012 by the Brazilian Public Opinion and Statistical Institute (IBOPE), to assess the number of individuals who consider themselves as vegetarians. In this survey results showed that an average $8 \%$ of respondents, selected in major capital cities and metropolitan regions of Brazil, consider themselves as vegetarians.

\section{Theoretical Background}

The theoretical background is made up basically of content regarding the vegetarianism and also regarding the concepts of perceived value and perceived sacrifice and its typology and classification. 


\section{Vegetarianism}

A vegetarian is someone who excludes from their diet meat, or meat derivative products and/or other animal origin products (such as eggs, milk and honey). Among vegetarian people there may be a great variety of dietary patterns, and they also differ in the extent to which products of animal origin are excluded from consumption (CRAIG; MANGELS, 2009; FRANCO; REGO, 2005).

A vegetarian diet can be classified among: egg-lactovegetarian which is based on the consumption of vegetables, dairy products and eggs; lactovegetarian which is based on the consumption of vegetables and dairy products, but excludes the consumption of eggs and egg products; egg-vegetarian which is based on the consumption of vegetables and eggs, but excludes the consumption of dairy products and their derivatives. In these variations of vegetarianism, the individual may or may not include the consumption of honey (FRANCO; REGO, 2005).

There is also a vegan diet, either called total or pure vegetarianism, which has, as a eating pattern, the exclusion of animal derived products such as meat, eggs, milk, honey, its derivatives and any other animal origin products. Furthermore, vegan individuals avoid the consumption of products made from animal testing or animal secretions, and do not use wool or leather (CRAIG; MANGELS, 2009; FRANCO; REGO, 2005).

Individuals advocating vegetarianism exclude from their meals any type of meat, however, to be a vegetarian does not mean having diets based only on vegetables. A vegetarian diet is primarily based on the consumption of cereals, fruits, legumes, vegetables, seeds, algae and mushrooms; but, preparations were also found including milk, eggs and honey derivatives (NUNES, 2010).

The estimated number of vegetarians in the world is 1.5 billion, of which only 75 million are vegetarians by choice and this number is expected to increase gradually to the extent that increase wealth and education. There are 1.45 million individuals who adhere, by necessity, the vegetarian diet; and, therefore, the increase of the purchasing power in this group can generate the inclusion of meat in their diet (LEAHY; LYONS; TOL, 2010).
The understanding of the increase in the number of vegetarians requires knowledge about the motivations for an individual to opt for this type of diet. There are various motivations, being the main ones: health, respect for animal life, environmental sustainability (LEAHY; LYONS; TOL, 2010), religion, ethics or philosophy perception (BRIGNARDELLO et al., 2013; GUIMARÃES，2011; RODRIGUES，2012; NUNES, 2010).-

\section{Perceived Value And Perceived Sacrifice}

The perceived value for the customer is directly related to an experience of using the product and depends on his or her perception, that is, it cannot be determined by the supplier; and, moreover, the value for the customer involves a trade-off between what the customer perceives to receive in the product (quality, benefits, performance, for example) and what he perceives to have spent for the acquisition and/ or use of the product (price, monetary sacrifices, effort, for example) (WOODRUFF, 1997). Thus, it is understood as a broader and richer construct than the concept of perceived price (SÁNCHEZFERNÁNDEZ; INIESTA-BONILLO, 2006).

The assumptions that the concept of perceived value has a direct relationship with the experience of using the product and that it is the consumer who perceives value in the product (not the value be determined by supplier) were also identified by Zeithaml (1988), Bigné, Moliner and Callarisa (2000), Roig et al. (2006) and Cengiz and Kirkbir (2007). The second assumption is also emphasized in studies by Vargo and Lusch (2004) and Leroi-Werelds et. al (2014).

In addition, two other aspects about the concept of perceived value by the consumer were presented by Woodruff (1997), and referenced by Morar (2013) and Chahal and Kumari (2012): (i) the value perceived by the consumer may vary according to the moment of the purchasing process (pre-purchase, use and post-purchase) and the situations of consumption experienced by the client and (ii) the value perceived by the consumer can be expected during the purchase process or use experience.

In short, the perceived value can be conceptualized as the overall assessment that the consumer makes about the usefulness of a product, based on the perceptions of the costs (expenditures or sacrifices) incurred and benefits (gains) received (ZEITHALM, 1988). Thus, an important aspect of this definition is that 
the perceived value relates to a bidirectional exchange, which represents an equation composed by gains and expenditures (SÁNCHEZ-FERNÁNDEZ; INIESTABONILLO, 2007; CENGIZ; KIRKBIR, 2007)

The perceived value could vary from consumer to consumer. There are cases in which the low price is what influences the perception of value; in others, is the balance between quality and price (CENGIZ; KIRKBIR, 2007).

Sánchez-Fernández and Iniesta-Bonillo (2006) drew up the Table 1 - Definitions of value to the consumer - in which are organized some papers that addressed different approaches of the concept of perceived value.

Table 1. Definitions of value perceived for the Consumer

\begin{tabular}{|l|l|}
\hline \multicolumn{1}{|c|}{$\begin{array}{c}\text { APPROACH } \\
\text { OF VALUE } \\
\text { PERCEIVED }\end{array}$} & \multicolumn{1}{|c|}{ AUTHORS } \\
\hline Value as low price & Oliva (2000) \\
\hline $\begin{array}{l}\text { Value as something } \\
\text { that the consumer } \\
\text { wishes in a product }\end{array}$ & $\begin{array}{l}\text { Afuah (2002); Butz and } \\
\text { Goodstein (1996); Hunt and } \\
\text { Morgan (1995); Van der Haar, } \\
\text { Kemp and Omta (2001) }\end{array}$ \\
\hline $\begin{array}{l}\text { Value as the quality } \\
\text { that the consumer } \\
\text { receives for the price } \\
\text { paid }\end{array}$ & $\begin{array}{l}\text { Dodds, Monroe and Grewal } \\
\text { (1991); Fornell } \text { et al. (1996); Gale } \\
\text { (1994); Lichtenstein, Netemeyer } \\
\text { and Burton (1990); Monroe } \\
\text { (1990); Sinha and DeSarbo } \\
\text { (1998) }\end{array}$ \\
\hline $\begin{array}{l}\text { Chen and Dubinsky (2003); } \\
\text { Holbrook (1994, 1999); } \\
\text { Holbrook and Corfman } \\
\text { (1985); Kothandaraman and } \\
\text { Wilson (2001); Lapierre (2000); } \\
\text { Liljander and Strandvik (1993); } \\
\text { McDougall and Levesque (2000); } \\
\text { Oliver (1999); Rust and Oliver } \\
\text { (1994); Sirohi, Mclaughlin } \\
\text { and Wittink (1998); Slater and } \\
\text { Narver (2000); Walter, Ritter and } \\
\text { Gemunden (2001); Woodruff } \\
\text { (1997); Zeithaml (1988) }\end{array}$ \\
$\begin{array}{l}\text { Value as something } \\
\text { that the consumer } \\
\text { receives for what he } \\
\text { or she gives }\end{array}$ \\
\hline
\end{tabular}

Source: Sánchez-Fernández and Iniesta-Bonillo (2006, p. 49)

In Table 1, the first approach is based on economic theory, in which the value relates to the monetary price of the product. However, price is a complex variable, because certain individuals have no monetary value as the primary determinant regarding purchase decision (CHERNATONY; HARRIS; RILEY, 2000; SÁNCHEZ-FERNÁNDEZ; INIESTA-BONILLO, 2006). In addition, it is not the price that sets the value of a product to the customer (SÁNCHEZFERNÁNDEZ; INIESTA-BONILLO, 2006).

In the second approach the value is related to the benefits and usefulness that a product can be deliver to the consumer, so that the customer achieves his goals (SÁNCHEZ-FERNÁNDEZ; INIESTABONILLO, 2006).

Regarding the third approach, there are several criticisms because relevant aspects are not considered and also because it may not be credible regarding the consumer assessment value (SWEENEY; SOUTAR, 2001; SÁNCHEZ-FERNÁNDEZ; INIESTABONILLO, 2006). Yet, the literature on perceived value emphasized the quality of the product as the main gain obtained by the consumer and the price as the main expenditure (SÁNCHEZ-FERNÁNDEZ; INIESTA-BONILLO, 2006).

The last approach seeks to aggregate the aspects of other settings to conceptualize the value for the consumer balancing benefits and perceived sacrifices (SÁNCHEZ-FERNÁNDEZ; INIESTABONILLO, 2006).

The marketing literature review allows to observe that the concept of perceived value is often related to an exchange between the values or gains received (benefits) and costs or sacrifices incurred by the purchase of a product (BLOCKER; FLINT, 2007; WOODRUFF, 1997, BLOCKER, 2011; PERREA; GRUNERT; KRYSTALLIS, 2014).

Among the models on perceived value, with multidimensional approach, the work of Sheth et al. (1991) is very highlighted. In this, the authors determined a set of possibilities of value, which form perceived and evaluated dimensions by customers, in their decision-making process of purchase (SÁNCHEZFERNÁNDEZ; INIESTA-BONILLO, 2007).

This model is referred to as "Theory of the Market Choice Behavior" (CHI; KILDUFF, 2011) or "Theory of Consumption Value" (SÁNCHEZFERNÁNDEZ; INIESTA-BONILLO, 2007). In it, the purchase decision of a plural individual involves various perceptions of value, such as functional, 
social, emotional, epistemic and conditional (CHI; KILDUFF， 2011; SÁNCHEZ-FERNÁNDEZ; INIESTA-BONILLO, 2007; WOODRUFF, 1997; CHAHAL; KUMARI, 2012; MORAR, 2013; CHANG; DIBB, 2012).

Furthermore, Sanchez et al. (2006) highlights that the definition of perceived value as a set of benefits (such as economic, social and relationship), and sacrifices (such as price, time, effort, risk and convenience) is present in several studies (DODDS; MONROE; GREWAL, 1991; BIGNÉ; MOLINER; CALLARISA, 2000; OH, 2003).

Such value dimensions can be described as follows:

- - Functional value means that the consumer realizes usefulness in the possession of the product, regarding its performance, its ability to perform the function for which it was created and its physical aspects.

- - Social value is relative to the social image that consumers want to be related to by the use of a particular product. This image, desired by individuals, must be in accordance with certain demographic, socioeconomic groups and/or cultures considered ethical.

- - Emotional value is related to the perception of usefulness for the consumer about the creation and perpetuation of feelings or affective states desired, either positive (for example, trust or excitement) or negative (e.g., fear or anger).

- - Epistemic value occurs when the consumer realizes usefulness on products/services that instigate their curiosity, either because they are new and/or for the satisfaction of a desire for knowledge.

- - Conditional value is the result of a situation in which physical or social background constraints impact on the usefulness perception by the consumer (SHETH et al., 1991; CENGIZ; KIRKBIR, 2007; SÁNCHEZ-FERNÁNDEZ; INIESTA-BONILLO，2007; BOKSBERGER; MELSEN, 2011; CHANG; DIBB, 2012).

The sacrifices are consistent with the dimensions of perceived value, but they are related to the opposite concept of perceived value. More specifically, in the case of monetary value, the consumers perceive higher value when the price of the product is lower than their expectation. In an opposite way, monetary sacrifice is noticed when the price of the product is higher than the expectation. The social value is associated with the positive images of the product given by other people. Regarding the social sacrifice, there are the negative images (BOKSBERGER; MELSEN, 2011; SANCHEZ et al., 2006; DODDS; MONROE; GREWAL, 1991).

\section{Methodology}

The instrument of data collection (structured interview script) was composed by the initial categories of perceived value described in the theoretical framework, which are: functional values, emotional values, social values and conditional values. The concepts and the theoretical descriptions of such categories were taken into account for the elaboration of questions which made up the interview script (PERREA; GRUNERT; KRYSTALLIS, 2014; HSU; LIN, 2015; NITIWANAKUL, 2014; MORAR, 2013; ZEITHALM, 1988; SHETH et al., 1991; WOODRUFF, 1997; SWEENEY; SOUTAR, 2001; PETRICK, 2002; SÁNCHEZ-FERNÁNDES; INIESTA-BONILLO, 2006, 2007; SANCHEZ et al., 2006).

In the case of monetary values, they are not modified according to the type of product or according to the interviewees' culture. They will always be based on an assessment of price and the cost of the product or service, generating a perception of being cheap or expensive.

The epistemic value was not considered in this research, due to the fact that many vegetarians have had this kind of diet for many years and thus it cannot be considered a new product or a novel in the market. In addition, this is not a type of value used on scales of perceived values existing on the market, such as the scale Perval of Sweetney and Soutar (2001) or the scale Serv-Perval of Petrick (2002) or even the scale Gloval by Sanchéz et al. (2006).

The script content of data collection is described in the table 2 as follows. 
Table 2. Questions regarding the interview script

\begin{tabular}{|c|c|}
\hline $\begin{array}{l}\text { VALUE OR } \\
\text { SACRIFICE }\end{array}$ & QUESTION TOPIC \\
\hline \multirow{3}{*}{ Functional } & $\begin{array}{l}\text { What are the major benefits in eating } \\
\text { vegetarian food? }\end{array}$ \\
\hline & $\begin{array}{l}\text { What are the major problems in eating } \\
\text { vegetarian food? }\end{array}$ \\
\hline & $\begin{array}{l}\text { Describe what are the goals to be } \\
\text { reached by eating vegetarian food. }\end{array}$ \\
\hline \multirow{2}{*}{ Social } & $\begin{array}{l}\text { What are the impressions or positive } \\
\text { opinions that other people may have } \\
\text { of you, because you eat vegetarian } \\
\text { food? }\end{array}$ \\
\hline & $\begin{array}{l}\text { What are the impressions or negative } \\
\text { opinions that other people may have } \\
\text { of you, because you eat vegetarian } \\
\text { food? }\end{array}$ \\
\hline \multirow{2}{*}{ Emotional } & $\begin{array}{l}\text { What are the positive feelings that you } \\
\text { feel when you choose to eat vegetarian } \\
\text { food? }\end{array}$ \\
\hline & $\begin{array}{l}\text { What are the negative feelings that you } \\
\text { feel when you choose to eat vegetarian } \\
\text { food? }\end{array}$ \\
\hline \multirow[b]{2}{*}{ Conditional } & $\begin{array}{l}\text { What are the facilitating factors for } \\
\text { you to consume vegetarian food? }\end{array}$ \\
\hline & $\begin{array}{l}\text { What are the factor that make it } \\
\text { difficult for you to consume vegetarian } \\
\text { food? }\end{array}$ \\
\hline
\end{tabular}

Source: elaborated by the authors.

The sample was composed by vegetarian people chosen by sampling procedure "Snow Ball". Thus, vegetarians known to the authors of the article and who participated in the interviews also indicated other vegetarian people, who were interviewed and also indicated other vegetarians and so forth.

A total of 15 interviews were performed and all of them were recorded for subsequent transcription and possibility of more detailed evaluation. The criterion for the definition of the sample size was the saturation of data and of the information obtained. Each interview lasted on average 17 minutes, and in total 4 hours and 21 minutes of recording time were obtained.

The data analysis process considered the initial categories of perceived values and sacrifices by the consumer.
It was applied the technique of content analysis (BARDIN, 2016), in which the items of each question were classified according to the similarity of the meaning and content of each response, generating the intermediate categories. These intermediate categories were associated initially to the category in which the question was associated.

Due to the theoretical concepts, in spite of the questions being related to each of the values or sacrifices, there might be that some answers are elated to any of the other three values. For example, when asked about the benefits on eating vegetarian food, the interviewee was able to come with functional factors, but he or she was also able to come up with emotional, conditional, social or even monetary factors.

\section{Data Analys}

The qualitative analysis, although examining the frequency of items contained in the responses of the interviewees, was carried out to identify the items that comprise the categories of perceived value, i.e., functional value and functional sacrifice emotional value and emotional sacrifice, social value and social sacrifice and conditional value and conditional sacrifice in relation to consumption of vegetarian food.

\section{Functional Value and Functional Sacrifice}

In the case of the main benefits regarding eating vegetarian food, a total of 94 opinions were identified. These opinions were grouped in intermediate categories to facilitate the analysis process and the meaning identification. Thus, three categories stood out in relation to the others, grouping approximately $76.6 \%$ of all opinions about the benefits of being vegetarian food consumers.

The main category was "well-being" related strongly to the "disposition feeling", described by opinions such as: "sense of physical well-being," "better willingness", "feel more willing”, "willingness", "after the meal, I am much more willing than a person who eats meat", "have better willingness provision", among others. In addition, the physical well-being was also often exhibited as a result of a facilitated digestive process, according to the items: "less heavy food (sensation)", "faster digestion", "easier digestion", "my digestion has improved," "positively 
affects the digestion", "I have a very calm digestion", "I don't have the feeling of weight that the meat gives", among other opinions. In addition, the feeling of lightness is also a physical well-being perceived by the respondents in the consumption of vegetarian food and it is present in the items: "I feel lighter", "feel lighter physically", "you feel lighter (in relation to the amount of food ingested being smaller)", etc. As the benefit of emotional well-being (psychological, mental) respondents said: "I feel better myself", "I feel with more life", "“feeling of tranquility due to consistency with the personal values", "I improved emotionally" and alike.

The second intermediate category in number of opinions was "Health", that is a benefit arising from the perception that the vegetarian food is healthy. Many respondents believe that it is healthier than non-vegetarian food (food with meat). This belief is related to the presence of the word "more" in some items, which can be understood as "more than" and denotes a comparison. It should be noted that this aspect of comparison is commonly present in the perception of respondents because the vast majority (except one person) has already been a meat consumer and, in the same way, prevails among respondent's coexistence with non-vegetarian persons. This health benefit provided by the vegetarian food is contained in the following items: "vegetarian food is healthier", "I feel healthier," "I think that my health improved a little when I became a vegetarian because in addition to stop eating meat and its derivatives, I stopped eating a number of industrialized products", "my health is another, I have a very good health", "reflects positively on health" and alike. In addition, more specific physical health benefits were listed by the respondents, such as: "loss of body weight," "change in sweat and in liquids expelled by the body", "my smell (body) has changed", "my body reduced the swelling too", "in the same period in which I stopped eating meat, my menstrual cramps have decreased a lot," "improvement in the skin", among other benefits.

The third intermediate category with the largest number of views was the "discovery of new foods, new flavors and different food preparations." The interviewees reported that the discovery (also described as exploration, experimentation, creativity and learning) results from the change in their feed habits and it is necessary for adaptation to the vegetarian diet. The following expressions show such benefits: "explore new foods", "people who choose to eat vegetarian food tend to discover (try) new foods", "become a vegetarian, the creative process for eating has to be better", "try new foods", "when you become vegetarian, you learn to mix many things, make many different flavors", in addition to other opinions.

The other opinions were classified into categories such as "nutritional benefits - better food" ("rich diets, in nutritional terms", "eat more fiber", "I think that we pay more attention to what you will eat (think and choose)", "it is more careful with what you'll eat", among others), "variety of food/vegetarian food" ("supply more diverse", "eat a greater variety of foods", "many food options (for example, soybean)", etc.) and "change in taste" ("better perception of food", "improves the taste feeling, realizing the better the flavor of food" and "change in taste").

The financial economy was also an item mentioned (only two citations), but it is classified as monetary value and not functional value. There were a few isolated opinions that were not classified in any of the intermediate identified categories.

Furthermore, the responses to the question about the goals to be achieved by consuming vegetarian food also showed other functional benefits in consuming this type of food. A large part of the respondents indicated that there was not a specific objective to be achieved and only 20 views were obtained. The main objectives were "not contribute to animal suffering or prevent animals from suffering", "contribute to environmental preservation" and "change feed habits" by means of expressions such as: "To start with, it is not to encourage relationships that cause animals suffering", "do not contribute (avoid/stop) the animals ill-treatment, which occurs in the meat industry", "do not contribute to animal suffering", "a proposal for environmental preservation for the people who are around me", "environmental preservation", reduce consumption of dairy products," "evolve in the process of vegetarianism by consuming only vegetables".

Regarding the benefits perceived in vegetarian food, it is important to highlight the health benefits that also appeared as a result of the research by Souza et al. (2013), in which the opinion of 50 vegetarian respondents from the Facebook group "Vegetarians Fortaleza" was raised in January 2013. Thus, in a Likert scale of 5 points, it was obtained the average score 4,52 for the question "In my opinion, vegetarian foods are healthier." This average demonstrates respondents' perception that vegetarian food has health benefits. 
In a similar way, Kumar and Kapoor (2015) surveyed 282 households in two cities in India to find the most valued attributes by consumers in vegetarian products (fruits and vegetables) and found the most important attributes: freshness, nutrition and medicinal value of this type of food. These results indicate a relationship between the most valued attributes in the vegetarian food and the perceived value by the consumer, in both cases related to health.

Another interesting result found in Brazilian researches and consistent with the present study concerns the intention of individuals to become vegetarians for issues related to animal welfare (RODRIGUES et al., 2012).

In relation to the functional sacrifices of consumption of vegetarian food, respondents issued a total of 53 opinions, which were grouped into intermediate categories for facilitating their understanding. The three main categories, which represent approximately $73.58 \%$ of all opinions are: "little option (variety) of vegetarian food", "high price of vegetarian food" and "food with nutrient deficiency". In the case of high price this item will not be taken into account because it is a monetary sacrifice and not functional sacrifice.

The intermediate category "little variety of vegetarian food" can be described as a problem related to the variety that occurs both in terms of consumption of vegetarian food away from home, in meals in the food service (restaurants, bars, coffee shops and companies in the sector), as the overall market for the purchase of processed foods (for example, yogurt, ice cream, burgers, sausage vegetarian, other similar). Such difficulties were shown in the following beliefs: "it is difficult to find options for vegetarian food in restaurants," "few restaurants have vegetarian options", "there are only vegetarian options with carbohydrates", "difficulty finding restaurants with a choice of vegetarian food," "difficulty finding variety of vegetarian food on the street", "difficulty finding variety of vegetarian food (outside home) when going to other places (travel) with nonvegetarian persons", "in cafeterias options are bread or cheese bread", "it is a discomfort because there are has fewer choices of place to everyone go (which have vegetarian food)", "difficulty finding options that are always satisfactory for everyone", "get out of the house and sometimes eat something really good", "because you have other moments (in addition to lunch time) when we are in the street and it is difficult to eat something that is nutritious and vegetarian”, "difficulty finding options for vegetarian food to cook at home", "difficulty finding options for vegetarian food prepared in the market (for example, burger of soybean)" and alike.

The other intermediate category related to perceived sacrifice is "food with nutrient deficiency", whose concern with nutritional questions and an inadequate nutritional diet are emphasized by the respondents through the excerpts of testimonies as: "possibility of having problems related to nutrition", "high consumption of carbohydrates", "I am afraid of having any nutritional deficiency", "the nutritional status worries me", etc.

On the perception of possible nutritional problems, Abonizio (2016) states that in his research he analyzed everyday situations related to vegetarianism and at one time he recorded two informal conversations about the abandonment of the vegetarian diet due to concern about nutritional and health issues. In both cases, vegetarians received a medical recommendation to return meat consumption for health reasons (one for low immunity and one for loss of muscle mass). In these cases, the actors of the research presented medical arguments for such perception. However, these nutritional and health recommendations regarding the importance of meat consumption (often not scientifically grounded) are present in the common sense and therefore feed the idea that the vegetarian diet can lead to nutritional and health problems.

In addition, other intermediate categories that could be identified were the "lack of confidence in the quality of food", which is perceived by consumers in terms of the hygiene of foodstuffs, related to the origin of the food, about the quality of the food and on the confidence that the food indeed is vegetarian, and the "difficulty in identification of vegetarian food available in the food service" which is a problem for consumers, as explained in the following items: "Problem to buy vegetarian food, especially in restaurants, on the basis of poor or lack of identification on the food being vegetarian or not" and "sometimes there is little information about it, you arrive in a place and you do not know whether that is vegetarian and/or vegan".

Another intermediate category identified in this topic was the "difficulty in social interaction" through relationship problems (such as "other people make jokes and offensive jokes because I am a vegetarian”, "sometimes makes it a little difficult socialization with people who are not vegetarians because going out 
usually involves eating - due to fewer choices of places that have vegetarian food -", "In the beginning too when I became a vegetarian - I had a bit of trouble with people who offered meat. I was a bit unsure of what to do, how to deny to this person without him or her being offended"). In the qualitative analysis, respecting the respondents' opinion, these items were evaluated on the topic of dimension of functional sacrifice. However, for the construction of categories considering the theoretical concepts already described, this category will be considered as belonging to the social dimension.

Furthermore, other opinions were identified regarding the functional sacrifice, but it was not possible to classify them in none of the intermediate categories already described.

Therefore, in the case of vegetarian food, items related to the nutritional aspects of food that corroborate the definition of functional value have been found, such as the consumer's perception of the utility of the product, due to its performance, its ability to perform the function for which it was created and its physical aspects (SHETH et al., 1991; CENGIZ; KIRKBIR, 2007; SÁNCHEZ-FERNÁNDEZ; INIESTABONILLO, 2007; BOKSBERGER; MELSEN, 2011; CHANG; DIBB, 2012). In the opposite sense, the perception of functional sacrifices related to the nutritional problems caused by the consumption of vegetarian food was also identified. In both cases, the functionality of this product refers to its performance.

\section{Social Value and Social Sacrifice}

The other category of perceived value was the social value. In this case, 58 opinions were obtained, on which four intermediate categories were identified which represent $67.24 \%$ of the total of opinions.

The intermediate category with the largest number of opinions was "to be vegetarian is something positive," which was determined through different expressions such as 'it is cool', admire, 'consider positive', 'something you want'. Such perceptions can be verified in the following opinions: "people find it cool", "people admire", "people have a positive perspective about vegetarianism", "people see as something positive" and alike.

The second intermediate category with the largest number of opinions was "vegetarian is a healthier lifestyle", which is represented by opinions as: "People think I have a healthier life", "people think I have a healthier diet", "people think I am eating more healthily (in nutritional terms)", "people think I have a more balanced diet ", "people think I am fitness", "people think I practice sports", "people think I do not consume alcohol", among other similar opinions.

The third and fourth intermediate categories; obtained the same number of opinions. In the case of the intermediate category "vegetarian has the willpower and reaches a very difficult goal" was appointed as positive impression or opinion from other people in the vision of the interviewees, because they realize that others see difficulty in not eating meat and its derivatives, so it would be an act of willingness of the vegetarian individual to abstain from something that they cannot, even if they want to. The fourth intermediate category is that "in spiritual terms vegetarian is a person more evolved" is a positive impression or opinion of others, due to the consumption of vegetarian food. The respondents explain that in some cases this "evolution" is related to a spiritual aspect, in others not; sometimes, there is also a connection with religion.

In addition, other intermediate categories that could be identified were "vegetarian is a thin person", "the vegetarian has empathy and respect for animals", "the vegetarian is a quiet person", "the vegetarian has more consciousness", as well as others who have an interest in becoming vegetarian.

As occurred in the previous categories, some opinions could not be classified in intermediary categories which were created for the social value.

In this study, social values related to the projection of a positive image of the vegetarian individual by third parties were identified, which is in line with the conceptualization of social value as the social image that the consumer wishes to have recognized in himself by the use of a particular product, when it is aligned with certain demographic, socioeconomic and / or ethical cultures (SHETH et al., 1991; CENGIZ; KIRKBIR， 2007; SÁNCHEZ-FERNÁNDEZ; INIESTA-BONILLO, 2007; BOKSBERGER; MELSEN, 2011; CHANG; DIBB, 2012). It should be noted that, in this case, the use (consumption) of the product "vegetarian food" presupposes abdicating the consumption of other products containing meat and / or other animal products. 
In relation to the category social sacrifice, the qualitative analysis identified a total of 77 opinions, considering that four intermediate categories contains a little more than half of all opinions, with $55.84 \%$.

The intermediate category with the largest number of opinions is "vegetarian is not a healthy person", which is a perception related to the possible nutritional problems stemming from the vegetarian diet. The following opinions suggest this type of perception: "people talk that I will be malnourished", "people think I will go sick", "people think I do not have a normal diet", "people think I have an inadequate worse/weaker diet (in nutritional terms)", "people talk that I will get anemic," "people say that meat is really important," "people think that I lack protein". It is worth noting that these negative impressions or opinions many times are based on a comparison between the vegetarian and non-vegetarian food, because a large part of these other people have a diet based on the consumption of meat and it is common belief about the importance of meat consumption.

The second intermediate category with the largest number of opinions was "it is difficult to cook or prepare food for a vegetarian person", usually involves the socialization between vegetarian and non-vegetarian people in meal times. These notes can be found at the following points of view: "people think that it is difficult to cook for me", "people think I am a problem when they will prepare some food for me", "people think I do not eat anything", "people think I do not like anything", as well as other similar perceptions.

The third intermediate category with the largest number of opinions was the "disagreement or misunderstanding of others" about the decision to eat vegetarian food and, in some cases, a contestation. These beliefs are identified from: "people do not understand (have no interest in understanding) the reason of my choice", "some people of my family did not agree with my choice", "some people do not respect my choice", among other similar beliefs.

The fourth category with the largest number of opinions is "vegetarian is boring or "difficult", which is present in the following opinions: "people think I am annoying", "people think I am 'eco-annoying", "people think I am 'difficult", "people think this is all about annoying".
Moreover, other intermediate categories were also identified, such as: "concern of others with the satisfaction of the vegetarian individual with the food served", "to be vegetarian is something negative", "the vegetarian is a strange person", "the vegetarian is a difficult person on social life" and "the vegetarian is a radical person". Other opinions were identified, but it was not possible to include them in any of the intermediate categories about the social sacrifice.

In terms of sacrifices, it should be noted that in the study by Rodrigues et al. (2012) were also found negative perceptions and attitudes of third parties in terms of incomprehension towards the vegetarian, and the vegetarians claimed to suffer prejudice and resistance from relatives, friends and acquaintances; in addition to being sometimes the subject of offensive comments, jokes and criticism. This sacrifice is classified as "social sacrifice."

Still in the case of social sacrifices, related to the perception of other people about the vegetarian, in the study of Souza et al. (2013) the results indicate, contrary to the results found in the present study, that vegetarians perceive few problems in terms of other people's opinions about their food choice.

\section{Emotional Value and Emotional Sacrifice}

In relation to the emotional perceived value, a total of 72 opinions were identified and four intermediate categories contain $50 \%$ of these opinions.

The intermediate category with the largest number of views is the "absence of guilt or clean conscience". It is a positive feeling that appeared more often related to non-contributing to animal suffering, also said as sacrifice or death of animals. This is present in the following beliefs: "by not eating meat, I do not feel guilt for the animal suffering", "I feel free, I no more feel guilty for not eating meat", "well under the impact of guilt and sorrow than if I ate meat", among other beliefs with the same meaning. It is worth noting that this absence of guilt is a consequence of the option of not eating meat, i.e., such a feeling is possible because there is a comparison between eating meat and eating vegetarian food. The non-contribution to issue of animal suffering and environmental degradation also generate in respondents positive feelings related to the clean conscience, as the following items: "I feel that I am not contributing to the deforestation", "I feel that I 
am not contributing to animal exploitation", "I feel that I am not contributing to animal suffering" and alike.

The second intermediate category with the largest number of opinions was the tranquility, which is a feeling that appeared frequently in the responses, as it can be observed: "I feel spiritual tranquility", "I feel peace in knowing that I am following what I believe (being correct)", "I feel calm because I am not causing suffering (animal)", "with a clear conscience because sometimes I am doing a good thing for animals, even without wanting to." Despite not using the word tranquility the item "I feel good, because according to my religion I believe that I will not have any negative feedback for never having eaten meat and have no "debts" with the animals" shows a similar feeling. In addition, it is worth noting that this tranquility is the result of several factors, such as having attitudes consistent with personal values, not to feel worried about nutritional questions and zeal for the animal well-being.

The third category with the largest number of opinions is to "be doing a good for me and for others", which can be understood as doing something that feels right and that expected to generate positive results and that can be observed by the following statements: "in the beginning, when I became a vegetarian, I felt that I was doing a good for me", "in the beginning, when I became a vegetarian, I felt that I was doing a good for humanity", "I feel that I am doing a good for the world", among other similar statements.

The fourth intermediate category most often cited was "empathy, love and affection" represented by positive feelings for their choice to eat vegetarian food. The items that describe such feelings are: "I feel that I have an empathetic relationship with the animals", "I feel that I relate better with people," "I feel love for animals", "I feel love for nature", among other similar opinions.

In addition, other intermediate categories that could be identified for the emotional value were "making the right choice and be ethically correct", "emotional well-being" and "physical well-being or feel better physically." In the case of these last two categories, they also were identified as benefits of consuming vegetarian food and, considering the number of citations for each category, the content of the interviews, as well as the theoretical concepts, it was decided to classify them as functional value, since they are related more to physical and mental well-being than in relation to more generic feelings of well-being.

ISSN 1982-2596
It is important to consider, once more, that some opinions could not be classified into intermediate categories created for the emotional value.

Similar results regarding emotional values were found by Souza et al. (2013), finding the absence of guilt and the feeling of making the right choice, by vegetarian consumers, as a result of consuming vegetarian food.

In relation to the emotional sacrifice, only 10 opinions were identified, being that the vast majority of respondents do not perceive negative feelings in consuming vegetarian food. The intermediate category identified in this case was to "nuisances generated in situations of social interaction, i.e., the person feels upset or annoyed with others", identified by means of the following beliefs: "in the past, when I became a vegetarian, I felt embarrassed", "in the past, when I became a vegetarian, I felt out of place ('a fish out of water')", "I feel bored (upset) because depending on the comments I always put myself in the role of defense because I am different", "sometimes I feel rejected in certain environments", as well as other similar beliefs. Other perceptions, also identified, were not classified as belonging to the intermediate category.

Thus, considering the approach that has value to the consumer as a balance between benefits and perceived sacrifices (SÁNCHEZ-FERNÁNDEZ; INIESTABONILLO, 2006), and taking into account only the emotional value, it is understood that, in the case of vegetarian food, consumers interviewed perceived high emotional value in view that few items were found related to the perception of emotional sacrifices.

\section{Conditional Values and Conditional Sacrifices}

In relation to the factors that facilitate the consumption of vegetarian food, i.e., conditional values, it was identified a total of 75 opinions. One of the most mentioned items was the issue regarding price - $12 \%$ of total of opinions. As previously described for other categories, this type of opinion is classified as monetary value.

The intermediate category with the largest number of opinions was the "care and respect from other people for the vegetarian person", which was described by respondents as one of the factors that will make it easier to eat vegetarian food. They described, as an important factor, for the zeal of people nearby, who 
have positive actions and often seek to make vegetarian food for them. In addition, they highlighted that the attitudes of people with whom they coexist are very significant for their well-being, once that this fact legitimates and supports their choice for vegetarianism. This facilitating aspect is present in the following statements: "my family is quiet about my choice to eat vegetarian food", "my family always prepares some vegetarian food for me", "my family eats vegetarian food that I do", "my family is vegetarian", "my family when are going to do something, a party, know that I do not eat meat, they make some food for me".

The second intermediate category with the largest number of opinions is the "ease of access and variety of vegetarian food", in the sense of diversity of natural food found for consumption and for the preparation of meals (for example, vegetables, fruits and vegetables), and also options available in the service supply (restaurants, bars, coffee shops, other similar establishments). In the following opinions it is possible to realize this: "I can find a variety of vegetarian foods", "there are more options for vegetarian food than food with meat", "I will never have a problem in the restaurant because there is always at least one option without meat, for example, a salad", "the access has improved too, you have had more opportunities to buy vegetarian things", "the availability of natural food is larger, easier", in addition to other views with similar content.

Other intermediate categories identified in relation to the conditional value were "enjoy cooking (personal pleasure)", "prepare your own food (convenience/ practicality)" and "ease in preparation and/or the conservation", in addition to other opinions that were not categorized in any of the intermediate categories.

In relation to conditional sacrifice, 55 opinions were identified, being that 8 of them were related to higher price of vegetarian food. This pricing problem is related to the monetary sacrifice. In relation to the intermediate categories the most important one, with more than half of the opinions about the conditional sacrifice was the "little availability of vegetarian food in the market (variety and access)", both in the service supply (at restaurants, bars, bakeries, coffee shops, and other establishments of food and beverage sector) and in terms of industrialized products sold in the commerce (for example, in supermarkets). In this sense, it was also mentioned the difficulty of finding vegetarian food at events and occasions such as at a party. Further, it can be noticed that the items in this category is common among respondents the complain that the vegetarian products do not fulfill their specific desires (for example, healthy vegetarian food or with low fat or no cheese). Nor is there a good variety of brands of industrialized vegetarian products (for example, sausages, hamburger, soybean), as perceived by respondents. In addition, this factor of scarcity leads to the need of the vegetarian consumer having to move with more frequency to certain establishments to be able to buy the product. These findings can be observed in the following beliefs: "in the restaurants the options of vegetarian food are restrict", "I have difficulty buying vegetarian food for my house", "the supermarkets do not always have vegetarian food", "often the choices of vegetarian food available in the supermarkets have many preservatives", "I have difficulty finding vegetarian food to buy", among other similar opinions.

On this incipient availability of satisfactory vegetarian food on the market, Franco and Rego (2005) emphasize the difficulties encountered by vegetarian consumers to dine out of the home, precisely because the food service ignores their motivations, needs and desires. In this sense, Rezende (2014) highlights the condition experienced by people who change from an omnivorous diet (diet that includes the consumption of meat and vegetables) to a vegetarian diet, because these individuals also change their buying patterns and, therefore, face problems related to the purchase of products in accordance with its political principles and access to information on products and businesses specialized in vegetarian food.

Other intermediate categories of conditional sacrifice identified were the "ignorance about vegetarianism and unwillingness to provide service to the vegetarian consumer" and the "difficulty in social interaction". Analyzing theoretical concepts, it was opted to classify it as belonging to the category of social sacrifice.

As occurs with the analysis of other categories, other opinions were identified, which were not classified in any of the intermediate categories related to conditional sacrifice.

\section{Monetary Values and Monetary Sacrifices}

As described in the theoretical framework, the monetary value - and the monetary sacrifice too are important dimensions of the perceived value by 
the customer. However, they were not considered in qualitative research because, unlike other types of value and of sacrifice, the contents of the monetary value - in principle - does not depend on the context of the time, place or the relative culture to the audience, as well as specific aspects to the product or service in question. In the case of this research, the price will be considered high or low by vegetarian consumers. The same is true for other types of product or service and also for different countries.

Despite of this, the price of vegetarian food - either high or low - was reported by the respondents in several opportunities in the intermediate categories of functional value, functional sacrifice, conditional value and conditional sacrifice.

\section{Final and Intermediate Categories}

From the information and analyzes carried out, it was proceeded to the summarization of results obtained in terms of final categories and the main intermediary categories through the organization of Table 3 , as follows

Table 3. The categories generated and their content generated from the qualitative research.

\begin{tabular}{|c|c|}
\hline FINAL CATEGORY & $\begin{array}{c}\text { INTERMEDIATE } \\
\text { CATEGORY }\end{array}$ \\
\hline \multirow{9}{*}{ Functional value } & Physical well-being \\
\hline & Mental well-being \\
\hline & Health (make me healthier) \\
\hline & $\begin{array}{l}\text { Discovery of new foods and/ } \\
\text { or new flavors and different } \\
\text { food preparations }\end{array}$ \\
\hline & $\begin{array}{l}\text { Nutritional benefits (better } \\
\text { food) }\end{array}$ \\
\hline & $\begin{array}{l}\text { Do not contribute to animal } \\
\text { suffering - avoid the animal } \\
\text { suffering }\end{array}$ \\
\hline & $\begin{array}{l}\text { Contribution for the } \\
\text { environmental preservation }\end{array}$ \\
\hline & Eating habits change \\
\hline & $\begin{array}{l}\text { Strengthening in my beliefs } \\
\text { and in what I believe }\end{array}$ \\
\hline
\end{tabular}

\begin{tabular}{|c|c|}
\hline \multirow{3}{*}{ Functional sacrifice } & $\begin{array}{l}\text { Little option (Variety) of } \\
\text { vegetarian food }\end{array}$ \\
\hline & $\begin{array}{l}\text { Feeding with nutrients } \\
\text { deficiency }\end{array}$ \\
\hline & $\begin{array}{l}\text { Lack of confidence on food } \\
\text { quality }\end{array}$ \\
\hline \multirow{7}{*}{ Social Value } & $\begin{array}{l}\text { Being a vegetarian is } \\
\text { something positive }\end{array}$ \\
\hline & $\begin{array}{l}\text { Vegetarian people have a } \\
\text { healthier lifestyle }\end{array}$ \\
\hline & $\begin{array}{l}\text { Vegetarian people have } \\
\text { willingness and reach harder } \\
\text { objectives }\end{array}$ \\
\hline & $\begin{array}{l}\text { When it comes to spiritual } \\
\text { terms, vegetarian people are } \\
\text { more evolved }\end{array}$ \\
\hline & Vegetarian people are thinner \\
\hline & $\begin{array}{l}\text { Vegetarian people have } \\
\text { empathy and respect for } \\
\text { animals }\end{array}$ \\
\hline & Vegetarian people are peaceful \\
\hline \multirow{8}{*}{ Social sacrifice } & $\begin{array}{l}\text { Vegetarian people are not } \\
\text { healthy }\end{array}$ \\
\hline & $\begin{array}{l}\text { It is hard to cook or prepare } \\
\text { food for a vegetarian person }\end{array}$ \\
\hline & $\begin{array}{l}\text { Disagreement or } \\
\text { misunderstanding of others }\end{array}$ \\
\hline & $\begin{array}{l}\text { Vegetarian people are boring } \\
\text { or "difficult" }\end{array}$ \\
\hline & $\begin{array}{l}\text { Other people's concern } \\
\text { with the satisfaction of the } \\
\text { vegetarian individual with } \\
\text { food }\end{array}$ \\
\hline & $\begin{array}{l}\text { Being a vegetarian is somewhat } \\
\text { negative }\end{array}$ \\
\hline & A vegetarian person is weird \\
\hline & $\begin{array}{l}\text { A vegetarian is a difficult } \\
\text { person when it comes to } \\
\text { social coexistence }\end{array}$ \\
\hline \multirow{5}{*}{ Emotional value } & $\begin{array}{l}\text { Absence of guilty feeling or } \\
\text { light conscience }\end{array}$ \\
\hline & Peacefulness \\
\hline & $\begin{array}{l}\text { Doing good things for myself } \\
\text { and for the others }\end{array}$ \\
\hline & Empathy, love and affection \\
\hline & $\begin{array}{l}\text { Doing the right choice and } \\
\text { being ethically correct }\end{array}$ \\
\hline Emotional sacrifice & $\begin{array}{l}\text { Nuisances generated in } \\
\text { situations of social interaction, } \\
\text { that is, the vegetarian feels } \\
\text { bored or upset with other } \\
\text { people }\end{array}$ \\
\hline
\end{tabular}




\begin{tabular}{|c|c|}
\hline \multirow{5}{*}{ Conditional Value } & $\begin{array}{l}\text { Care and respect from other } \\
\text { people with the vegetarian } \\
\text { person }\end{array}$ \\
\hline & $\begin{array}{l}\text { Access easiness and vegetarian } \\
\text { food variety }\end{array}$ \\
\hline & $\begin{array}{l}\text { Enjoy cooking (personal } \\
\text { pleasure) }\end{array}$ \\
\hline & $\begin{array}{l}\text { Preparing own food } \\
\text { (convenience/practicality) }\end{array}$ \\
\hline & $\begin{array}{l}\text { Easiness regarding the } \\
\text { preparation and/or } \\
\text { conservation }\end{array}$ \\
\hline \multirow[b]{2}{*}{ Conditional sacrifice } & $\begin{array}{l}\text { Limited availability of } \\
\text { vegetarian food on the market } \\
\text { (variety and access) }\end{array}$ \\
\hline & $\begin{array}{l}\text { Ignorance about vegetarianism } \\
\text { and unwillingness to provide } \\
\text { services to the vegetarian } \\
\text { consumer }\end{array}$ \\
\hline Monetary value & $\begin{array}{l}\text { Perception of lower price of } \\
\text { vegetarian food }\end{array}$ \\
\hline Monetary sacrifice & $\begin{array}{l}\text { Perception of higher price of } \\
\text { vegetarian food }\end{array}$ \\
\hline
\end{tabular}

Source: research data.

\section{Final Considerations}

The present study aimed to identify the items that make up the intermediate categories of perceived values and sacrifices, and therefore the final categories of perceived values and sacrifices. The perceived value can be considered as a comparison among the functional, emotional, social, monetary and conditional values, with the functional, emotional, social, monetary and conditional sacrifices.

The theoretical contributions of this work are diverse. Initially, it may be noted that the results of qualitative research are the "raw material" for the preparation of a questionnaire in order to measure the perceived value of vegetarian food.

In addition, the questions contained in the interview script of this research can be adapted for other types of product, different from the vegetarian food. Moreover, the obtained results allow the preparation of other questionnaires with specific items related to the product in question, which may be used for the measurement of the perceived value of this specific product.

Another theoretical contribution of this study is the deeper understanding about the values and sacrifices that vegetarian consumers face in relation to their consumption habits. The results obtained are quite large in relation to the potential benefits and values perceived by consumers of vegetarian food, as well as the results related to the sacrifices or the disadvantages in consuming vegetarian food were quite detailed and extensive. It should also be noted that the level of detail obtained in the responses to each of the types of perceived values and sacrifices allows not only the categorization, but also the expansion of the knowledge about the consumption behavior of vegetarians and their perceptions about this consumption.

In relation to the managerial implications of the results obtained in this study, there are many opportunities for several participants in the chain of vegetarian food, which can increase the perceived value and, at the same time, decrease the perceived sacrifice on the part of consumers. Marketing communication can emphasize the aspects considered positive by vegetarian consumers, such as the expansion of the mix of vegetarian products of the establishment, the confidence in food preparation, and service provided by trained staff to attend the needs of this public. This marketing communication generates changes in products management. Price is an important item for consumers and the market can be a factor of differentiation from sales over the internet and social media and possibility of delivery. The problems encountered by vegetarians in finding places with a good variety of products, besides the location itself, are also factors that should be considered by the managers. Social media appear as a great opportunity for companies, since that there is a view that vegetarian consumers have a tendency of being engaged and form communities where their type of food is the "common bond" among the participants, as it was shown during the collection of data, to access the interviewees. So, when you become known and respected by a group of vegetarians, there is the possibility of rapid expansion along the various individuals in that group or community. In terms of product, new varieties of vegetarian products can be created considering the most valued aspects by their consumers. In this way, one must consider the satisfaction of the desires of vegetarian individuals who show discontent at not finding diversified options of vegetarian food in the food service, and who wish to buy different vegetarian products such as sausage, sausages and hamburgers. 
In the case of the limitations of the research, the most important of them is related to the sampling used, which makes it impossible to generalize the results obtained. Moreover, this is an exploratory research, which has intrinsic limitations regarding the possibility of results generalization. In addition, there are different type of vegetarian consumers, where everyone does not eat meat, but some do not eat eggs, other milk derivatives and so on. The important thing in this case is that the perception of values and sacrifices may be different for diverse groups of vegetarians. For example, finding food can be easy or hard for any group, the social pressure of friends can be different for each group and so forth, influencing the results of the intermediate categories of values and of the perceived sacrifices.

In relation to future research, from the definition of categories of perceived value and perceived sacrifice, as well as their respective intermediate categories, it is possible to perform a descriptive quantitative research with a view to not only measure the perceived value and the perceived sacrifice, as well as testing the dimensionality of these categories, the reliability of the scales, as well as verify their convergent validity, discriminant validity and the nomological validity of this model of perceived value to the vegetarian food according to their consumers.

In addition, some divergent opinions were identified. In this case, the research analysis is correct, because, by means of the qualitative technique it is was possible to identify the opinions of individuals. Thus, perceptions about the price of vegetarian food, its level of availability in the market, as well as the nutritional content of vegetarian food, presents diverse opinions and at different levels among the interviewees. Therefore, this fact also justifies further studies with descriptive approach to identify those characteristics among vegetarians.

Finally, differences in the perception of value and the perception of sacrifices among the vegetarian demographic characteristics, such as gender, age, income, the type of vegetarianism practiced and the vegetarian diet time of the individual, should also be investigated.

\section{References}

ABONIZIO, J. Conflitos à mesa: vegetarianos, consumo e identidade. Revista Brasileira de Ciências Sociais, v. 31, n. 90, p. 115-137, 2016.

BARDIN, L. Análise de conteúdo. 1 ed. São Paulo: Edições 70, 2016. 279p.

BIGNÉ, J. E.; MOLINER, M. A.; CALLARISA, L. J. El valor y la fidelización de clientes: propuesta de modelo dinámico de comportamiento. Revista Europea de Dirección y Economía de la Empresa, v. 9, n. 3, p. 65-78, 2000.

BLOCKER, C. P. Modeling customer value perceptions in cross-cultural business markets.

Journal of Business Research, v. 64, n. 5, p. 533 540, 2011.

BLOCKER, C. P.; FLINT, D. J. Customer segments as moving targets: integrating customer value dynamism into segment instability logic. Industrial Marketing Management, v. 36, n. 6, p. 810-822, 2007.

BOKSBERGER, P. E.; MELSEN, L. Perceived value: a critical examination of definitions, concepts and measures for the service industry. Journal of Services Marketing, v. 25, n. 3, p. 229-240, 2011.

BRIGNARDELLO, J.; HEREDIA, P. L.; PAZ, M. O. S.; DURAN, S. A. Conocimientos alimentarios de vegetarianos y veganos chilenos. Revista Chilena Nutrición, v. 40, n. 2, p. 129-134, 2013.

CENGIZ, E.; KIRKBIR, F. Customer perceived value: The development of a multiple item scale in hospitals. Problems and Perspectives in Management, v. 5, n. 3, p. 252-268, 2007.

CHAHAL, H.; KUMARI, N. Consumer perceived value: The development of a multiple item scale in hospitals in Indian context. International Journal of Pharmaceutical and Healthcare Marketing, v. 6, n.2, p. 167-190, 2012.

CHANG, C.; DIBB, S. Reviewing and conceptualising customer-perceived value.

Marketing Review, v. 12, n. 3, p. 253-274, 2012.

CHERNATONY, L. de; HARRIS, F.; RILEY, F.

D. Added value: its nature, roles and sustainability.

European Journal of Marketing, v. 34, n. 1/2, p. 39-56, 2000. 
CHI, T.; KILDUFF, P. P. D. Understanding consumer perceived value of casual sportswear: an empirical study. Journal of Retailing and Consumer Services, v. 18, n. 5, p. 422-429, 2011.

CRAIG, W. J.; MANGELS, A. R. Position of the American Dietetic Association: Vegetarian Diets. Journal of the American Dietetic Association, v. 109, n. 7, p. 1266-1282, 2009.

DODDS, W. B.; MONROE, K. B.; GREWAL, D. Effects of price, brand and store information on buyers' product evaluations. Journal of Marketing Research, v. 28, n. 3, p. 307-319, 1991.

ESPINOZA, F. S.; HIRANO, A. S. As dimensões de avaliação dos atributos importantes na compra de condicionadores de ar: um estudo aplicado. Revista de Administração Contemporânea, v. 7, n. 4, p. 97 117, 2003.

FRANCO, É. de S.; REGO, R. A. Marketing estratégico para subculturas: um estudo sobre hospitalidade e gastronomia vegetariana em restaurantes da cidade de São Paulo. Turismo - Visão e Ação, v. 7, n. 3, p. 469-482, 2005.

GUIMARÃES, M. L. Os riscos microbiológicos e nutricionais da cozinha vegetariana. 2011. 75 f. Dissertação (Mestrado em Segurança e Qualidade Alimentar). Escola Superior de Engenharia e Turismo do Estoril. Estoril, Portugal, 2011.

HSU, C.-L.; LIN, J. C.-C. What drives purchase intention for paid mobile apps? - An expectation confirmation model with perceived value. Electronic Commerce Research and Applications, v. 14, n. 1, p. 46-57, 2015.

\section{INSTITUTO BRASILEIRO DE OPINIÃO} PÚBLICA E ESTATÍSTICA - IBOPE. Dia Mundial do Vegetarianismo: 8\% da população brasileira afirma ser adepta do estilo. 2012. Disponível em: < http:/ /www. ibope.com.br/pt-br/noticias/Paginas/Dia-Mundialdo-Vegetarianismo-8-da-populacao-brasileira-afirmaser-adepta-ao-estilo.aspx>. Acesso em: 24 set. 2015.

KUMAR, N.; KAPOOR, S. Does the consumers' buying behavior differ for vegetarian and nonvegetarian food products? British Food Journal, v. 117, p. 1998-2016, 2015.

LEAHY, E.; LYONS, S.; TOL, R. S. J. An estimate of the number of vegetarians in the world. ESRI working paper, Dublin. $n^{\circ}$. 340, 2010.
LEROI-WERELDS, S.; STREUKENS, S.; BRADY, M. K.; SWINNEN, G. Assessing the value of commonly used methods for measuring customer value: a multi-setting empirical study. Journal of the Academy Marketing Science, v. 42, n. 4, p. 430451, 2014.

MORAR, D. D. An overview of the consumer value literature - perceived value, desired value. In: The Proceedings of the International Conference" Marketing-from Information to Decision", Babes Bolyai University, p. 168-186, 2013.

MOURA, L. R. C. Um Estudo Comparativo de Teorias da Ação e Suas Extensões Para Explicar a Tentativa de Perder Peso. 2010. 403 f. Tese (Doutorado em Administração) - Universidade Federal de Minas Gerais, Belo Horizonte, 2010.

MOURA, L. R. C.; Cunha, N. R. da S.; Porto, G. D.; Moura, L. E. L. de; Pires, R. R. Desenvolvimento de uma nova versão de escala para mensuração das características que incentivam a adoção de novos produtos: um estudo sobre a água mineral. NavusRevista de Gestão e Tecnologia, v. 5, n. 4, p. 96112, 2015.

MOWEN, J. C.; MINOR, M. Consumer behavior: A framework. Upper Saddle River, New Jersey: Prentice-Hall, 2001.

NITIWANAKUL, W. A comparative study of customer perceived value as a driver for fine dining restaurant selection: a case of thai consumers and expatriates. Au Journal of Management, v. 12, n. 1, p. 1-13, 2014.

NUNES, E. L. M. Vegetarianismo além da dieta: ativismo vegano em São Paulo. 2010. 129 f. Dissertação (Mestrado em Ciências Sociais) Pontifícia Universidade Católica de São Paulo, São Paulo, 2010.

$\mathrm{OH}, \mathrm{H}$. Price fairness and its asymmetric effects on overall price, quality, and value judgements: The case of an upscale hotel. Tourism Management, v. 24, n. 4. p. 387-399, 2003.

PERREA, T.; GRUNERT, K.G.; KRYSTALLIS, A. Consumer Value perceptions of food products from emerging processing technologies: Across-cultural exploration. Food Quality and Preference. v. 39, p. 95-108, 2014. 
PETRICK, J. F. Development of a multi-dimensional scale for measuring the perceived value of service. Journal of Leisure Research, v. 34, n. 2, p. 119134, 2002.

REZENDE, D. C. de. Politics in food markets: alternative modes of qualification and engaging. Revista de Sociologia e Economia Rural, v. 52, n. 2, p. 387-400, 2014.

RODRIGUES, A. R. A Construção da Identidade Social por meio do Consumo Vegetariano: um estudo netnográfico. 2012. 216f. Dissertação (Mestrado em Administração) - Universidade Federal de Lavras, Lavras, 2012.

RODRIGUES, A. R. et al. O vegetarianismo como estilo de vida e postura de consumo: uma análise dos fatores influentes na adoção de uma dieta vegetariana. In: VI Encontro Nacional de Estudos do Consumo e II Encontro Luso-Brasileiro de Estudos do Consumo, 2012, Rio de Janeiro. Anais... Rio de Janeiro: [s.n.], 2012. p. 1-20.

ROIG, J. C. F.; GARCIA, J. S.; TENA, M. A. M.; MONZONIS, J. L. Customer perceived value in banking services. International Journal of Bank Marketing, v. 24, n, 5, p. 266-283, 2006.

SÁNCHEZ, J.; CALLARISA, L.; RODRÍGUEZ, R. M.; MOLINER, M. A. Perceived value of the purchase of a tourism product. Tourism Management, v. 27, n. 3, p. 394-409, 2006.

SÁNCHEZ-FERNÁNDEZ, R.; INIESTABONILLO, M. Á. Consumer Perception of Value: Literature Review and a New Conceptual Framework. Journal of Consumer Satisfaction, Dissatisfaction and Complaining Behavior, v. 19, p. 40-58, 2006.

SÁNCHEZ-FERNÁNDEZ, R.; INIESTABONILLO, M. Á. The concept of perceived value: A systematic review of the research. Marketing Theory, v. 7, n. 4, p. 427-451, 2007.

SHETH, J. N.; NEWMAN, B. I.; GROSS, B. L. Why we buy what we buy: A theory of consumption values. Journal of Business Research, v. 22, n. 2, p. 159-170, 1991.

SOUZA, A. C. A. A. de et al. Fatores Relevantes para o Comportamento de Consumidores Vegetarianos. In: XVI SEMEAD - Seminários em Administração, Anais... São Paulo, 2013.
SWEENEY, J. C.; SOUTAR, G. N. Consumer perceived value: The development of a multiple item scale. Journal of Retailing. v. 77, n. 2, p. 203-220, 2001.

VARGO, S. L.; LUSCH, R. F. Evolving to a new dominant logic for marketing. Journal of Marketing, v. 68, n. 1, p. 1-17, 2004.

ZEITHAML, V. A. Consumer perceptions of price, quality and value: a means-end model and synthesis of evidence. Journal of Marketing, v. 52, n. 3, p. 2-22, 1988. 